\title{
Arabinose with LL-Diaminopimelic Acid in the Cell Wall of an Aerobic Coryneform Organism Isolated from Human Skin
}

\author{
By D. G. PITCHER \\ Institute of Dermatology, St John's Hospital for Diseases of the Skin, London E9 $6 B X$
}

(Received II December I975)

INTRODUCTION

The human cutaneous aerobic diphtheroids have often been classified in the genus Corynebacterium and various specific names have been proposed in the past. However, these organisms show such a bewildering variety of colonial, morphological and biochemical characteristics that they now warrant a detailed taxonomic study in order to determine their generic status.

Following the work of Cummins \& Harris (1956), analysis for wall components has become a valuable taxonomic weapon. It is generally accepted that most pathogenic and commensal strains of corynebacteria of animal origin characteristically possess mesodiaminopimelic acid (meso-DAP) and arabinogalactan in their walls (Cummins, I97I): such walls are classed as type IV (Lechevalier \& Lechevalier, 1970).

This paper describes six organisms with a coryneform morphology, which have LLdiaminopimelic acid (LL-DAP) and arabinose as their major wall components.

\section{METHODS}

Strains were received by courtesy of Professor R. van Furth, University Hospital, Leiden, The Netherlands, and were derived from a survey of the skin flora of dialysis and transplant patients (Noble, Rebel \& Smith, 1974).

All strains were inoculated on $5 \%(\mathrm{v} / \mathrm{v})$ horse serum agar plates and incubated aerobically for $48 \mathrm{~h}$ at $37^{\circ} \mathrm{C}$. Colonial characteristics were noted and the coryneform morphology confirmed by Preston and Morrell's modification of the Gram stain (Cowan \& Steel, 1965). Batch culture was carried out at $37^{\circ} \mathrm{C}$ with shaking in I 1 Erlenmeyer flasks containing brain-heart infusion broth (Oxoid). Cells were harvested in late-exponential growth.

The method of preparation of purified walls, hydrolysis conditions and chromatographic techniques for amino acids, amino sugars and neutral sugars, were those described by Cummins \& Johnson (1971). The biochemical tests used were those of Cowan \& Steel (1965) or Somerville (1973). Thin-layer chromatography for the detection of mycolic acids was carried out on dried whole cells using the acid methanolysis technique of Minnikin, Alshamaony \& Goodfellow (1975a).

\section{RESULTS}

A total of 136 aerobic diphtheroids were subjected to wall analysis. The majority of strains possessed meso-DAP and arabinogalactan, but six strains were isolated in which only LL-DAP, arabinose and mannose were found as major components. These six isolates were obtained from different patients and from four different skin sites (toewebs, nose, shin and chest). In none of the patients was a strain isolated from more than one skin site. Plate 
Table I. Wall composition of the six strains

\begin{tabular}{lcccccc} 
& \multicolumn{7}{c}{ Strain } \\
\cline { 2 - 5 } & DI34 & D426 & D559 & D635 & D697 & D716 \\
LL-DAP & ++ & ++ & ++ & ++ & ++ & ++ \\
Alanine & +++ & +++ & +++ & +++ & +++ & +++ \\
Glutamic acid & ++ & ++ & ++ & ++ & + & +++ \\
Glycine & ++ & ++ & ++ & ++ & +++ & +++ \\
Glucosamine & +++ & +++ & +++ & +++ & +++ & +++ \\
Galactosamine & - & ++ & + & +++ & - & - \\
Muramic acid & ++ & ++ & ++ & ++ & ++ & ++ \\
Arabinose & +++ & +++ & +++ & +++ & +++ & +++ \\
Mannose & ++ & ++ & ++ & ++ & ++ & ++ \\
Galactose & - & - & - & - & - & -
\end{tabular}

The amount present is indicated as increasing from + to $+++;-$, not detected.

counts carried out by Noble et al. (1974) showed that four of the strains were present in sufficient numbers for them to be considered as resident members of the cutaneous flora.

Colonial morphology on $5 \%(\mathrm{v} / \mathrm{v})$ horse serum agar was the same for all strains: a convex, shiny, white colony approximately $\mathrm{I}$ to $2 \mathrm{~mm}$ in diameter was obtained after $48 \mathrm{~h}$ at $37^{\circ} \mathrm{C}$. The microscopic appearance was of a small, non-motile, Gram-positive, pleomorphic bacillus showing snapping division and a strong tendency to clump. Metachromatic granules were not seen.

Strains were uniformly negative in the following tests: arginine hydrolysis; production of $\mathrm{H}_{2} \mathrm{~S}$ from cysteine; gelatin liquefaction; fluorescence on ' 199 ' medium; production of acid from glucose, galactose, fructose, maltose, sucrose, lactose and salicin. They were resistant to Furoxone (I00 $\mu \mathrm{g}$ disc, Oxoid), growth was not enhanced by $0.1 \%$ Tween 80 , and did not occur on MacConkey agar. All strains were catalase positive, oxidase positive, grew well under anaerobic conditions and on Hoyles tellurite medium, and in the presence of $7.5 \%$ $(\mathrm{w} / \mathrm{v})$ sodium chloride. The six strains varied in the biochemical characteristics of starch hydrolysis, nitrate reduction, urease activity and lipolysis of Tween 80 .

Amino acids, amino sugars and neutral sugars detected in hydrolysates of isolated walls were identified by comparison with reference compounds (Table I). No mycolic acids were detected by the acid methanolysis technique.

\section{DISCUSSION}

The morphological, cultural and biochemical features of these organisms are typical of those found for aerobic, cutaneous diphtheroids. However, the walls of the majority of diphtheroids contain meso-DAP, arabinose, galactose and usually mannose, with glycine either absent or present only in small amounts, whereas the six strains described possessed LL-DAP in conjunction with relatively large amounts of glycine. This observation is in agreement with published findings that in bacteria whose walls contain LL-DAP, peptidoglycan crosslinking occurs via glycine; but in bacteria whose walls contain meso-DAP there is usually no interpeptide bridge (Work, 1970; Schleifer \& Kandler, 1972). Cummins \& Johnson (1974) found LL-DAP in the walls of $4 \mathrm{I}$ out of 43 strains of Propionibacterium acnes, though in this case the accompanying sugars were glucose, mannose and galactose. These bacteria are found in large numbers on human skin, but are anaerobic in contrast to the six strains under discussion which grow very well aerobically. Other coryneforms that 
contain LL-DAP are the Arthrobacter simplex group, but in these the major sugar is usually galactose (Keddie, Leask \& Grainger, 1966). Arabinose in bacterial walls, accompanied by galactose and meso-DAP, is thought to be a characteristic of Mycobacterium, Nocardia and the animal corynebacteria. Bergey's Manual of Determinative Bacteriology (1974) suggests that this denotes a close relationship between the three genera.

The morphological, cultural and biochemical characteristics of the six strains closely resemble the description of Corynebacterium pseudodiphtheriticum in Bergey's Manual of Determinative Bacteriology (1974) but this species has a type IV wall and corynomycolic acids. The bacteria described here may be related to the animal corynebacteria since they possess an arabinose-mannose polymer, but perhaps for stereochemical reasons an arabinogalactan cannot co-exist with a peptidoglycan based on LL-DAP-glycine. Similar reasons might account for the absence of mycolic acids. No information is available as to whether mycolic acid-like lipids, occur in other LL-DAP containing organisms; and to date mycolic acids have only been associated with type IV walls (Cross \& Goodfellow, 1973) though type IV walls have been found where mycolic acids were absent (Minnikin, Alshamaony \& Goodfellow, I975 $b$ ).

It is suggested that though the six isolates cannot confidently be described as Corynebacterium sensu stricto, they are coryneforms of animal origin showing similarities to the corynebacteria of human skin and may belong to an, as yet, uncharacterized genus. Some qualitative and physiological differences occurred between the six strains, but an assessment of their taxonomic weight must await the isolation of more strains and more detailed characterization.

\section{REFERENCES}

Bergey's Manual of Determinative Bacteriology, 8th edn (I974). Edited by R. E. Buchanan and N. E. Gibbons. Baltimore: Williams \& Wilkins.

CowAN, S. T. \& STEel, K. J. (1965). Manual for the Identification of Medical Bacteria. Cambridge: Cambridge University Press.

Cross, T. \& Goodfellow, M. (1973). Taxonomy and clarification of the actinomycetales. In The Actinomycetales, pp. 11-12. Edited by G. Sykes and F.A. Skinner. London: Academic.

Cummins, C. S. (1971). Cell wall composition in Corynebacterium bovis and some other corynebacteria. Journal of Bacteriology 105, $1227-1228$.

Cummins, C.S. \& Harris, H. (1956). The chemical composition of the cell wall in some Gram-positive bacteria and its possible value as a taxonomic character. Journal of General Microbiology 14, 583-600.

Cummins, C. S. \& Johnson, J. L. (I97I). Taxonomy of the clostridia: Wall composition and DNA homologies in Clostridium butyricum and other butyric acid-producing clostridia. Journal of General Microbiology 67, 33-46.

Cummins, C. S. \& Johnson, J. L. (I974). Corynebacterium parvum: A synonym for Propionibacterium acnes. Journal of General Microbiology 80, 433-443.

Keddie, R. M., Leask, B. G. S. \& GRAINGER, J. M. (1966). A comparison of coryneform bacteria from soil and herbage: Cell wall composition and nutrition. Journal of Applied Bacteriology 29, $\mathbf{7 7 - 4 3 .}$

LecheValier, M. P. \& Lechevalier, H. (1970). Chemical composition as a criterion in the classification of aerobic actinomycetes. International Journal of Systematic Bacteriology 20, 435-443.

Minnikin, D. E., Alshamaony, L.\& Goodfellow, M. (1975a). Differentiation of Mycobacterium, Nocardia and related taxa by thin-layer chromatographic analysis of whole organism methanolysates. Journal of General Microbiology 88, 200-204.

Minnikin, D. E., Alshamaony, L. \& Goodfellow, M. (1975b). Lipid composition of Nocardiae and related bacteria. Proceedings of the Society for General Microbiology 3, 47.

Noble, W. C., Rebel, M. H. \& SMITH, I. (1974). An investigation of the skin flora of dialysis and transplant patients. British Journal of Dermatology 9x, $20 \mathrm{I}-207$.

Schleifer, K. H. \& KANDler, O. (1972). Peptidoglycan types of bacterial cell walls and their taxonomic implications. Bacteriological Reviews 36, 407-477.

Somerville, D. A. (1973). A taxonomic scheme for aerobic diphtheroids from human skin. Journal of Medical Microbiology 6, 21 5-224.

WORK, E. (1970). The distribution of diamino acids in cell walls and its significance in bacterial taxonomy. International Journal of Systematic Bacteriology 20, 425-433. 